\title{
"State funding of higher education as a factor of ensuring its quality: experience of the European countries"
}

\begin{tabular}{|c|c|}
\hline AUTHORS & $\begin{array}{l}\text { Olha Hryhorash (D https://orcid.org/0000-0002-8089-3755 } \\
\text { R https://publons.com/researcher/1976980/olha-v-hryhorash/ } \\
\text { Victor Chentsov (D https://orcid.org/0000-0002-1109-8168 } \\
\text { RI https://publons.com/researcher/1875835/victor-v-chentsov/ } \\
\text { Almagul Nurgaliyeva (D https://orcid.org/0000-0001-6449-8766 } \\
\text { Tetiana Hryhorash (D https://orcid.org/0000-0002-3000-1683 } \\
\text { R https://publons.com/researcher/1976982/tetiana-f-hryhorash/ }\end{array}$ \\
\hline ARTICLE INFO & $\begin{array}{l}\text { Olha Hryhorash, Victor Chentsov, Almagul Nurgaliyeva and Tetiana Hryhorash } \\
\text { (2020). State funding of higher education as a factor of ensuring its quality: } \\
\text { experience of the European countries. Public and Municipal Finance, 9(1), 60-69. } \\
\text { doi:10.21511/pmf.09(1).2020.06 }\end{array}$ \\
\hline DOI & http://dx.doi.org/10.21511/pmf.09(1).2020.06 \\
\hline RELEASED ON & Friday, 25 December 2020 \\
\hline RECEIVED ON & Tuesday, 18 August 2020 \\
\hline ACCEPTED ON & Saturday, 19 December 2020 \\
\hline LICENSE & $\begin{array}{l}(c) \text { EY } \\
\text { This work is licensed under a Creative Commons Attribution } 4.0 \text { International } \\
\text { License }\end{array}$ \\
\hline JOURNAL & "Public and Municipal Finance" \\
\hline ISSN PRINT & $2222-1867$ \\
\hline ISSN ONLINE & $2222-1875$ \\
\hline PUBLISHER & LLC "Consulting Publishing Company "Business Perspectives" \\
\hline FOUNDER & LLC "Consulting Publishing Company "Business Perspectives" \\
\hline
\end{tabular}

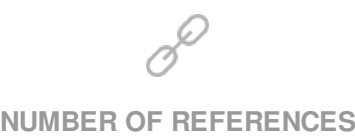

29
NUMBER OF FIGURES

3

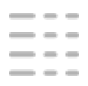

NUMBER OF TABLES

5

(C) The author(s) 2022. This publication is an open access article. 


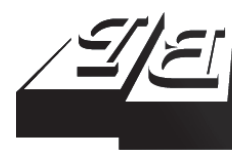

\section{BUSINESS PERSPECTIVES}

LLC "CPC "Business Perspectives" Hryhorii Skovoroda lane, 10, Sumy, 40022, Ukraine www.businessperspectives.org
Received on: $18^{\text {th }}$ of August, 2020 Accepted on: $19^{\text {th }}$ of December, 2020 Published on: $25^{\text {th }}$ of December, 2020

(c) Olha Hryhorash, Victor Chentsov, Almagul Nurgaliyeva, Tetiana Hryhorash, 2020

Olha Hryhorash, Ph.D. (Economics), Associate professor of the Department of State, Local and Corporate Finance, University of Customs and Finance, Ukraine. (Corresponding author)

Victor Chentsov, D. Sc. (History), D. Sc. (Public Management and Administration) / First Vice-Rector, University of Customs and Finance, Ukraine.

Almagul Nurgaliyeva, Ph.D., Faculty of Economics, Department of Management and Tourism, Kazakh University of Technology and Business Nur-Sultan city, Republic of Kazakhstan.

Tetiana Hryhorash, Senior Lecturer of the Department of State, Local and Corporate Finance, University of Customs and Finance, Ukraine.
Olha Hryhorash (Ukraine), Victor Chentsov (Ukraine),

Almagul Nurgaliyeva (Republic of Kazakhstan), Tetiana Hryhorash (Ukraine)

\begin{abstract}
The article presents a comparative analysis of state funding of higher education as a factor of its effectiveness in European countries. The analysis is conducted on the example of countries where the share of state budget expenditures on education is no less than $11 \%$.

The assumption that education is the main factor in the formation of a responsible citizens capable to provide the job themselves, and to provide qualified professionals for the country, that means to promote economic and cultural growth, is taken as a basis of the article.

The structure of state expenditures on education in general and the amount of higher education funding in countries under consideration are analyzed.

The correlation between the amount of expenditures on higher education and the indicators of the quality index of the higher education system QS World University Rankings is analyzed. Also, the correlation analysis between other indices that characterize the general level of human development and quality of business as a result of public investment in training of highly qualified specialists is done.
\end{abstract}

\section{Keywords higher education, funding, quality of education, European countries, Ukraine}

\section{JEL Classification H52, I22}

\section{INTRODUCTION}

European countries have a high level of life of the population. It is confirmed with the high positions of the European countries in the international ratings of human development and business.

The basis to achieve the high level of the human capital of the country as the driver of the economic, scientific and technical progress is the education level of the population and the quality of higher education. Specifically the quality of higher education describes the level of training specialists for economic and community development.

The main investor of the specialists' training is the government, whereas the funding of higher education is an indispensable item of public expenditures in each country. In addition to public expenditures, higher education is also funded with money resources, received from grant projects participation, as well as from private entities. At the same time, the government is responsible for financing the training of specialists to prepare staff members for public sector as well as for strategic sectors of the private business. 
It is necessary to assess the role of the government in the process of ensuring the development of higher education, i.e. to analyze the correlation between state funding of higher education and the quality of the higher education system in European countries, determined by the QS World University Rankings; between the level of human development and opportunities for economic development (doing business).

\section{LITERATURE REVIEW}

The government plays an important role in quality of education; it determines the education development policy and acts as a main investor in training specialists, who will participate not only in the development of economic activities but also in the socio-cultural state development in the future.

Stryhul et al. (2019), quote George Spring, who says that education investments lead to economic growth, reduce income inequality and increase employment. The authors emphasize that the state educational policy, as a component of social policy, is one of the state tools of influence on the social structure formation.

The successful implementation of the state educational policy is definitely connected with the education and higher education funding. Indeed, if government spending on university funding increase by $1 \%$, the Global Innovation Index increase by 0.375 over 4 years. Also, every additional $1 \%$ of people, who work with new technologies, annually increase the level of the Global Innovation Index by 0.75 (Stavytskyy et al., 2019).

On the other hand, the insufficient level of funding limits the state's ability to influence on the quality of education, and also on the quality of training specialists. In accordance with analysis of Ukrainian and Polish universities, the lack of financial resources is one of the reasons that prevent implementing the concept of social responsibility as a tool for sustainable social development for getting ready responsible citizens, who can care about the country's future, in educational institutions (Khovrak, 2020).

For this reason, in the United States the cutbacks of higher education funding on one hand and price increase for higher education on the other hand is considered negative. The number of future jobs will require specialists with higher education, but higher education becomes inaccessible (since
2008 the cost of education has increased by $24 \%$ ) (Mitchell et al., 2019; Geiger \& Kheller, 2012).

However, it is important to note that the amount of state funding for higher education does not always ensure its quality. Inefficient organization of the higher education system, even with a significant amount of public spending, the level of quality of higher education will be low. Research (Miningou, 2019) shows that in developing countries an average education expenditure is $16 \%$ of government spending. These countries feel a lack of funding on the one hand and low level of education quality on the other hand. The lack of financial resources forces educational institutions to constantly reduce the cost of educational services, which often leads to decrease in quality of training (Govindarajan \& Srivastava, 2020).

Developed countries are characterized by a high level of education quality, achieved by sufficient level of funding. Among other components of improvement the level of education, the authors find: continuous improvement of the resource base of research institutions, significant financial investment, high quality standards, wide access to higher education (Antoniuk et al., 2019). On the one hand higher education funding with non-state sources reduces the duties on the country's budget, on the other hand, limits the state's influence on education policy (A. Goksu \& G. Goksu, 2015).

The number of post-Soviet countries in particular Kazakhstan (Adambekova \& Amankeldy, 2016), Latvia (Hrishyn, 2011) and Ukraine (Dekhtiar \& Yanchenko, 2018) support the idea of the necessity to increase higher education funding and to increase cooperation with private investors and research customers, however, the higher education system and approaches to its funding obviously needs to be changed (Usyk, 2019; Antonyuk et al., 2017; Sovsun, 2016).

This article shows the analysis of economic component, which influences on the higher educa- 
tion quality - state funding. QS World University Rankings were selected as an indicator that characterizes the effectiveness of higher education systems in the analyzed countries. It is assumed that the efficiency of higher education systems is as higher as the government spending per student is higher.

\section{Aims}

The study aims to analyze the correlation between state funding of higher education and indicators that characterize the quality and efficiency of higher education in European countries. The goal achievement requires performing following tasks:

1. To analyze a direct significant correlation between education expenditures and the level of Gross enrolment ratio in Europe.

2. To evaluate the correlation between the amount of higher education funding per one student and the quality of the QS World University Rankings.

3. To analyze the correlation between the indicators of the human development index (as a factor of the business environment formation) and the quality of business climate to stimulate the economy.

\section{GENERALIZATION OF MAIN STATEMENTS}

Delivery of learning services to citizens is one of the functions of the state, so education expenditures is an indispensable item of public expenditures in each country. Usually, the structure of education expenditures is represented by the following components: pre-primary and primary education, secondary education, post-secondary non-tertiary education, tertiary education, and education not definable by level, subsidiary services to education, R\&D education etc.

The structure of public spending on education in European countries is presented in Table 1. European countries with the share of education expenditures exceeds $11 \%$ of total budget expenditures, were selected for analysis.

The data in Table 1 shows that Ukraine ranks the second in amount of education funding - 16.8\% of all budget expenditures, in first rank has Iceland $-17.4 \%$. Norway has the lowest amount of education funding at $11 \%$ of budget expenditures. The analysis shows that some countries rely on funding for pre-primary and primary education (Denmark, Sweden - more than 45\% of education expenditures), secondary education (Netherlands, Ukraine - more than $40 \%$ ) or

Table 1. The structure of public spending on education in some European countries and Ukraine in 2018

Source: Eurostat (2018), State Treasury Service of Ukraine (2018).

\begin{tabular}{|c|c|c|c|c|c|c|c|c|c|}
\hline Country & $\begin{array}{l}\text { Expenditure } \\
\text { on } \\
\text { education, } \\
\% \text { of total } \\
\text { expenditure }\end{array}$ & $\begin{array}{l}\text { Pre-primary } \\
\text { and primary } \\
\text { education }\end{array}$ & $\begin{array}{l}\text { Secondary } \\
\text { education }\end{array}$ & $\begin{array}{c}\text { Post- } \\
\text { secondary } \\
\text { non- } \\
\text { tertiary } \\
\text { education }\end{array}$ & $\begin{array}{l}\text { Tertiary } \\
\text { education }\end{array}$ & $\begin{array}{c}\text { Education } \\
\text { not } \\
\text { definable } \\
\text { by level }\end{array}$ & $\begin{array}{l}\text { Subsidiary } \\
\text { services to } \\
\text { education }\end{array}$ & $\begin{array}{c}\text { R\&D } \\
\text { education }\end{array}$ & $\begin{array}{l}\text { Education } \\
\text { n.e.c. }\end{array}$ \\
\hline Denmark & 12.6 & 45.5 & 25.2 & 0.0 & 24.6 & 1.7 & 0.9 & 0.6 & 1.4 \\
\hline Ireland & 12.6 & 42.1 & 34.8 & 1.0 & 15.6 & 1.6 & 2.3 & 0.0 & 2.6 \\
\hline Cyprus & 12.0 & 30.7 & 35.4 & 0.0 & 18.1 & 7.3 & 7.7 & 0.0 & 0.9 \\
\hline Latvia & 15.1 & 40.3 & 24.0 & 0.1 & 13.1 & 9.6 & 3.2 & 1.0 & 8.7 \\
\hline Lithuania & 13.4 & 19.9 & 37.5 & 5.1 & 16.9 & 8.0 & 0.8 & 4.6 & 7.2 \\
\hline Malta & 14.2 & 25.6 & 36.5 & 2.8 & 17.0 & 0.4 & 2.6 & 7.2 & 7.9 \\
\hline Netherlands & 12.1 & 28.8 & 40.5 & 0.0 & 28.0 & 0.0 & 2.2 & 0.4 & 0.1 \\
\hline Poland & 12.0 & 42.1 & 22.8 & 0.1 & 24.3 & 1.8 & 5.7 & 1.6 & 1.7 \\
\hline Slovenia & 12.4 & 37.9 & 35.9 & 0.0 & 17.7 & 2.0 & 4.6 & 0.1 & 1.9 \\
\hline Sweden & 13.8 & 63.6 & 15.7 & 0.2 & 15.7 & 2.9 & 0.3 & 0.0 & 1.4 \\
\hline Iceland & 17.4 & 43.8 & 30.6 & 0.0 & 20.0 & 1.4 & 2.5 & 0.0 & 1.7 \\
\hline Norway & 11.0 & 43.9 & 19.7 & 0.4 & 21.7 & 8.3 & 3.6 & 0.7 & 1.8 \\
\hline Switzerland & 16.5 & 22.2 & 30.4 & 0.0 & 22.6 & 20.2 & 1.9 & 1.3 & 1.5 \\
\hline Ukraine & 16.8 & 15.1 & 48.4 & 4.8 & 21.1 & 0.8 & 4.8 & 0.6 & 4.4 \\
\hline
\end{tabular}


higher education. For example, the Netherlands spends $28 \%$ of educational expenditures on higher education, Denmark - 24.6\%, Poland - 24.3\%, Ukraine - 21.1\%.

No matter how much the state education funding is provided, each level of education is one of the indicators of the state development generally. The Education Index is a component of the Human Development Index, which is published annually by the United Nations. The education index represents the literacy rate of the adult population (two thirds of the value) and the composite indicator of the total share of students (one third of the value). The literacy level allows finding out what percentage of the population is able to read and write, while the total share of students indicates the percentage of students from kindergarten to postgraduate education (UNDP, 2018). It is assumed that if public spending on education is high, the level of educational development will be higher.

Education expenditures and the education index are shown in Figure 1.

Analysis of the data in Figure 1 found that there is no direct significant correlation between the amount of education expenditures and the education index $\left(R^{2}=22.83 \%\right)$. This can be the cause of two reasons: the high quality of the education system, which allows ensuring a high level of education with low costs, or the significant amount of education costs from non-state sources of funding.

Concerning the higher education funding, the following should be noted. It is obvious that with different amounts of expenditures on education and higher education, the availability of higher education and gross enrolment ratio of higher education, are different in European countries. Table 2 presents the value of the gross enrollment ratio of higher education (\% of school-age population).

According to the data in Table 2, there is a trend: while the higher education expenditure is only $13.1 \%$ of education expenditure in Latvia, $88 \%$ of the population has higher education. It may be explained in the way that higher education is paid mostly by expenses of private entities, rather than direct budget funding. Ukraine spends $21.1 \%$ of education budget expenditures for higher education and has $83 \%$ of the population with higher education (the second rank). Kazakhstan spends $19.3 \%$ of budget expenditures on education (the highest rank), while the of share higher education is only $10.4 \%$ of this amount; the gross enrolment ratio (tertiary) is $53 \%$ of the population. $24.6 \%$ of all education expenditures are spent on higher ed-

Source: Eurostat (2018), State Treasury Service of Ukraine (2018), Ministry of Finance of the Republic of Kazakhstan (2018), UNDP, 2018.

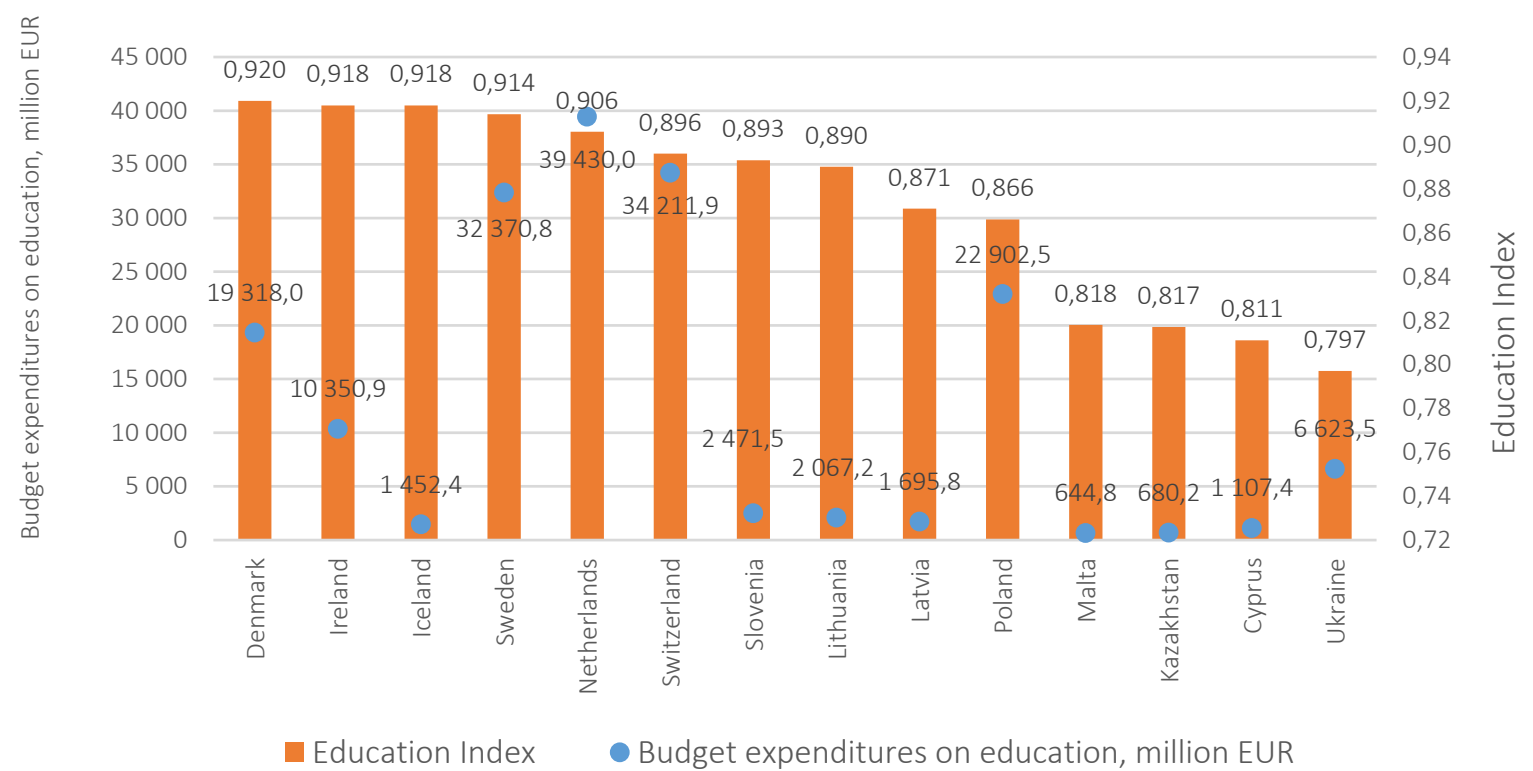

Figure 1. Education index and expenditures on education in some European countries and Ukraine in 2018 
Table 2. Gross enrolment ratio, tertiary (\% of tertiary school-age population) in European countries and Ukraine in 2018

Source: Eurostat (2018), State Treasury Service of Ukraine (2018), Ministry of Finance of the Republic of Kazakhstan (2018), UNDP (2018).

\begin{tabular}{|c|c|c|c|c|c|}
\hline Country & $\begin{array}{c}\text { Expenditure on } \\
\text { education } \\
\text { (\% of budget } \\
\text { expenditures) }\end{array}$ & $\begin{array}{l}\text { Expenditure on } \\
\text { higher education } \\
\text { (\% of education } \\
\text { expenditures) }\end{array}$ & $\begin{array}{c}\text { Government } \\
\text { expenditure on } \\
\text { tertiary education, } \\
\text { million euro }\end{array}$ & $\begin{array}{l}\text { Expenditures } \\
\text { per } 1 \text { student, } \\
\text { thousand euro }\end{array}$ & $\begin{array}{l}\text { Gross enrolment ratio, } \\
\text { tertiary (\% of tertiary } \\
\text { school-age population) }\end{array}$ \\
\hline Latvia & 15.1 & 13.1 & 222.0 & 2.7 & 88 \\
\hline Ukraine & 16.8 & 21.1 & $1,395.3$ & 7.0 & 83 \\
\hline Norway & 11.0 & 21.7 & $3,906.4$ & 13.5 & 82 \\
\hline Denmark & 12.6 & 24.6 & $4,759.7$ & 15.3 & 81 \\
\hline Netherlands & 12.1 & 28.0 & $11,034.0$ & 12.4 & 80 \\
\hline Ireland & 12.6 & 15.6 & $1,619.4$ & 7.0 & 78 \\
\hline Slovenia & 12.4 & 17.7 & 436.8 & 5.7 & 78 \\
\hline Iceland & 17.4 & 20.0 & 290.0 & 1.3 & 74 \\
\hline Lithuania & 13.4 & 16.9 & 348.9 & 2.9 & 71 \\
\hline Poland & 12.0 & 24.3 & $5,572.9$ & 3.7 & 67 \\
\hline Sweden & 13.8 & 15.7 & $5,092.9$ & 11.8 & 64 \\
\hline Cyprus & 12.0 & 18.1 & 200.2 & 4.2 & 60 \\
\hline Switzerland & 16.5 & 22.6 & $7,715.6$ & 25.2 & 58 \\
\hline Kazakhstan & 19.3 & 10.4 & 473.7 & 1.5 & 53 \\
\hline Malta & 14.2 & 17.0 & 109.7 & 7.2 & 49 \\
\hline
\end{tabular}

ucation in Poland and only $67 \%$ of the population has higher education. It can be assumed that the target audience of students in Poland is not only Poles, but also foreign students, in particular Ukrainian, because the procedure of studying in Poland is simpler than studying in Ukraine

Considering that the development of higher education is carried out both with budget state funding and non-governmental organizations, it is necessary to determine the degree of impact of public funding on the quality of higher education systems in European countries.

The QS Higher Education System Strength Rankings ranks countries the effectiveness of higher education systems on four indicators: the strength of the system (each country is awarded a score based on the number of its institutions which are ranked 700 or above in the QS World University Rankings ${ }^{\oplus}$, divided by the average position of those institutions. The aim is to give an overall indication of each country's standing in the global ranking tables), access (scores in this category are calculated based on the number of places available at universities ranked within the global top 500, divided by an indicator of population size), flagship institution (indicator is based on the premise that the performance of a coun- try's leading institution is a credit to the overall system, often resulting from national investment in developing a flagship institution to lead the way and economic context (aims to assess the impact of national investment in higher education, by comparing each nation's financial situation to its performance in the international rankings. And this is then factored against the GDP per capita for the country in question).

The comparison between the expenditures on higher education and the indicator of the higher education quality is shown in the Table 3.

According to Table 3, it is concluded that countries with the cost of higher education funding per student less than in Ukraine (6.8 thousand euros), are not shown in the list of 50 countries in the QS Higher Education System Strength Rankings-2018. The exception is Poland, where 5,572.9 million euros are spent on higher education, with a contingent of 1,492,899 students, an average amount is 3.7 thousand euros per student.

It can be assumed that there is a correlation between the amount of higher education funding (the amount of expenditure per student) and the QS World University Rankings (Figure 2). 
Table 3. QS Higher Education System Strength Rankings - 2018

Source: Eurostat (2018), State Treasury Service of Ukraine (2018), Ministry of Finance of the Republic of Kazakhstan (2018), UNDP, 2018.

\begin{tabular}{|c|c|c|c|}
\hline Country & $\begin{array}{c}\text { Expenditures per } 1 \text { student, } \\
\text { thousand euros }\end{array}$ & $\begin{array}{c}\text { QS Higher Education } \\
\text { System Strength Ranking }\end{array}$ & Overall Score \\
\hline Netherlands & 12.4 & 7 & 84.9 \\
\hline Switzerland & 23.5 & 13 & 75.6 \\
\hline Poland & 3.7 & 46 & 18.6 \\
\hline Sweden & 11.1 & 14 & 74.8 \\
\hline Denmark & 15.3 & 22 & 64.1 \\
\hline Norway & 13.5 & 30 & 51.4 \\
\hline Ireland & 7.0 & 24 & 58.9 \\
\hline Kazakhstan & 1.5 & 37 & 42.5 \\
\hline Ukraine & 6.8 & 44 & 23.7 \\
\hline Slovenia & 5.7 & - & - \\
\hline Lithuania & 2.9 & - & - \\
\hline Iceland & 1.3 & - & - \\
\hline Latvia & 2.7 & - & - \\
\hline Cyprus & 4.2 & - & - \\
\hline Malta & 7.2 & - & - \\
\hline
\end{tabular}

The data in Figure 3 shows that there is a correlation between higher education funding and the QS World University Rankings indicator. The determination factor is $44.17 \%$. The model is adequate to the observational evidence $F_{\text {emp }}=5.54>$ $F_{(0,1 ; 1 ; 7)}=3.59$ and has a significant parameter $t_{1}=$ $2.22>t_{(0,1 ; 7)}=1.89$. This means that the amount of funding for higher education determines almost half of its quality and efficiency.

The analysis of the correlation between the amount of expenditure per student and the com- ponents of the Higher Education Performance Index (QS World University Rankings) is presented in Table. 4.

According to data in Table 4, based on the correlation and regression analysis it was calculated the correlation, the determination factor, the adequacy of the model (according to the F-Fisher criterion) and the significance of the regression parameters (based on the Student's criterion). The calculation data are presented in Table 5.

Source: Made by authors.

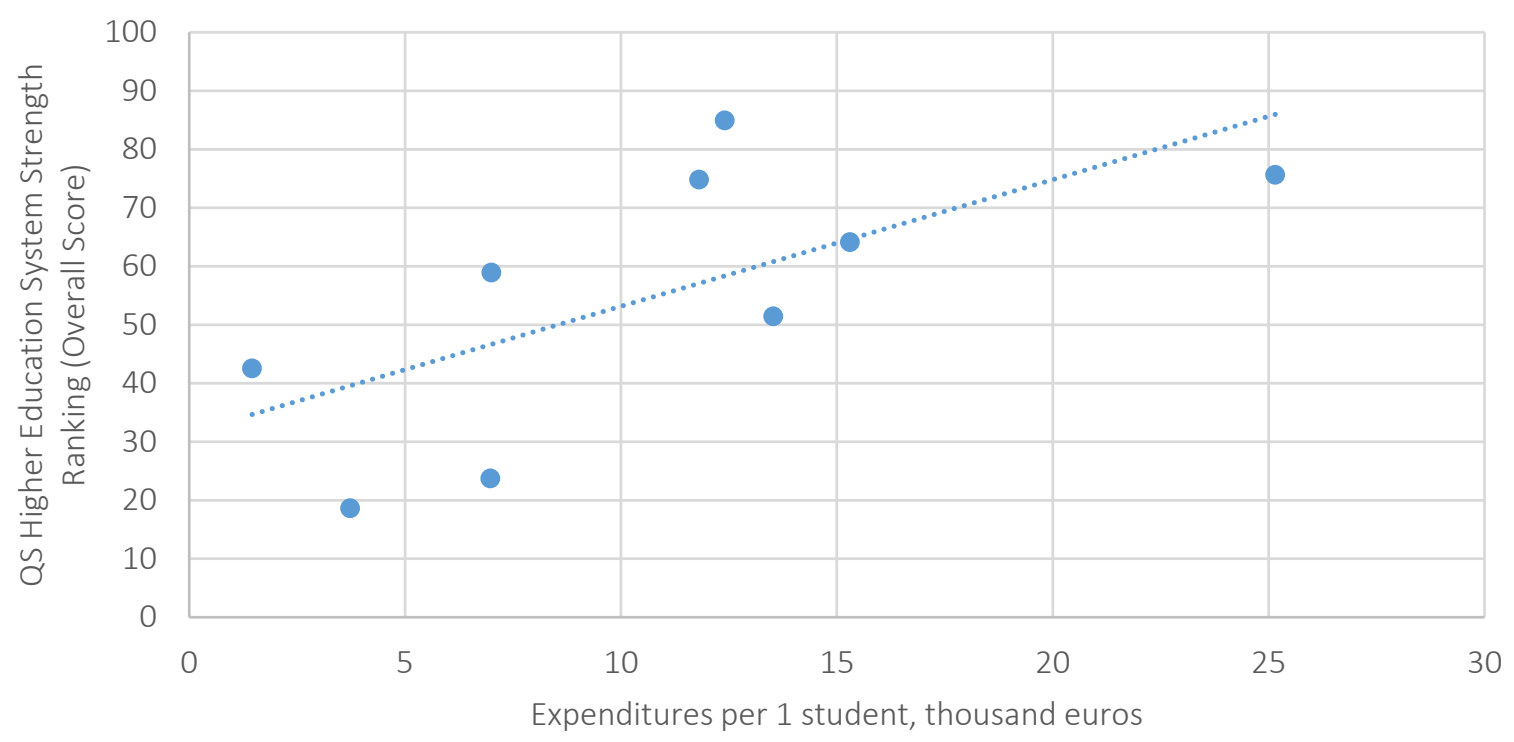

Figure 2. Analysis of the correlation between the amount of expenditure per student and the QS World University Rankings-2018 
Table 4. Components of QS World University Rankings-2018

Source: Eurostat (2018), State Treasury Service of Ukraine (2018), QS Top Universities (2018).

\begin{tabular}{|c|c|c|c|c|c|c|}
\hline Country & $\begin{array}{c}\text { Expenditures per } 1 \\
\text { student, thousand Euro }\end{array}$ & Overall score & System & Access & Flagship & Economy \\
\hline Netherlands & 12.4 & 84.9 & 89.3 & 87.7 & 92.7 & 69.8 \\
\hline Switzerland & 25.2 & 75.6 & 78.5 & 76.5 & 98.9 & 48.6 \\
\hline Poland & 3.7 & 18.6 & 14.10 & 38.5 & 7 & 14.60 \\
\hline Sweden & 11.8 & 74.8 & 73 & 83.4 & 88.7 & 54.1 \\
\hline Denmark & 15.3 & 64.1 & 54 & 78.1 & 89.6 & 34.8 \\
\hline Norway & 13.5 & 51.4 & 43.3 & 65.8 & 75.9 & 20.5 \\
\hline Ireland & 7.0 & 58.9 & 49.8 & 71.6 & 86.9 & 27.01 \\
\hline Kazakhstan & 1.5 & 42.5 & 37.6 & 35 & 51.6 & 45.7 \\
\hline Ukraine & 7.0 & 23.7 & 16.10 & 14.40 & 8.50 & 55.90 \\
\hline
\end{tabular}

Based on these calculations, the direct correlation between the amount of funding per student and the components of the QS World University Rankings index (system strength, accessibility, activities of institutions) was found (correlation ratio exceeds 0.6 ). The models are adequate to the observational data $\left(F_{\text {emp }}>F_{(0,1 ; 1 ; 7)}\right)$ and have significant parameters $t_{1}\left(t_{\text {emp }}>t_{(0,1 ; 7)}\right)$ for all components except the economic one. The parameter $t_{0}$ is significant for the component of availability and economic component, but the model based on the economic component is inadequate to the observational evidence.

Thus, it is determined that state funding of education in general, and higher education in particular, is not the main factor, that determines the effectiveness of higher education. The government is not the one investor to the higher education development, international grant programs are available for students, the level of literacy of the population begins with the level of education, and the quality of higher education determines the level of training specialists for country development.

Turning to the beginning of the analysis and the supposal that the level of higher education contributes to social and economic development, it is necessary to analyze the correlation between human development (HDI - human development index) and the ease of doing business (World Bank Group, 2018).

The HDI is the geometrical significance for each of the three measurements. The health component is estimated by the average life expectancy at birth, the educational component is measured by the average level of schooling for adults in the age of 25 and over and the life expectancy for school-age children. The living standard is measured by gross national income per capita. Then the scores of three components of the HDI indices are aggregated into an integrated index using the geometric significance (UNDP, 2018).

Table 5. Analysis of the correlation between expenditure per student and the components of the QS World University Rankings

Source: Made by authors.

\begin{tabular}{|c|c|c|c|c|c|}
\hline Indicator & $\begin{array}{c}\text { Expenditures per } 1 \\
\text { student, thousand Euro }\end{array}$ & Overall score & System & Access & Flagship \\
\hline$R$ & 0.6646 & 0.6657 & 0.6314 & 0.6656 & 0.2159 \\
\hline$R^{2}$ & 0.4417 & 0.4431 & 0.3987 & 0.4431 & 0.0466 \\
\hline$F_{(0,1 ; 1 ; 1 ;) \ldots}$ & 3.59 & 3.59 & 3.59 & 3.59 & 3.59 \\
\hline $\mathrm{F}_{\mathrm{emp}} \ldots \ldots$ & 5.54 & 5.57 & 4.64 & 5.57 & 0.34 \\
\hline$t_{(0,1,7) \ldots}$ & 1.89 & 1.89 & 1.89 & 1.89 & 1.89 \\
\hline$t_{1} \ldots \ldots$ & 2.3535 & 2.3601 & 2.1544 & 2.3598 & 0.5851 \\
\hline$t_{0}$ & 2.6925 & 1.8025 & 2.7254 & 1.6522 & 2.9256 \\
\hline
\end{tabular}




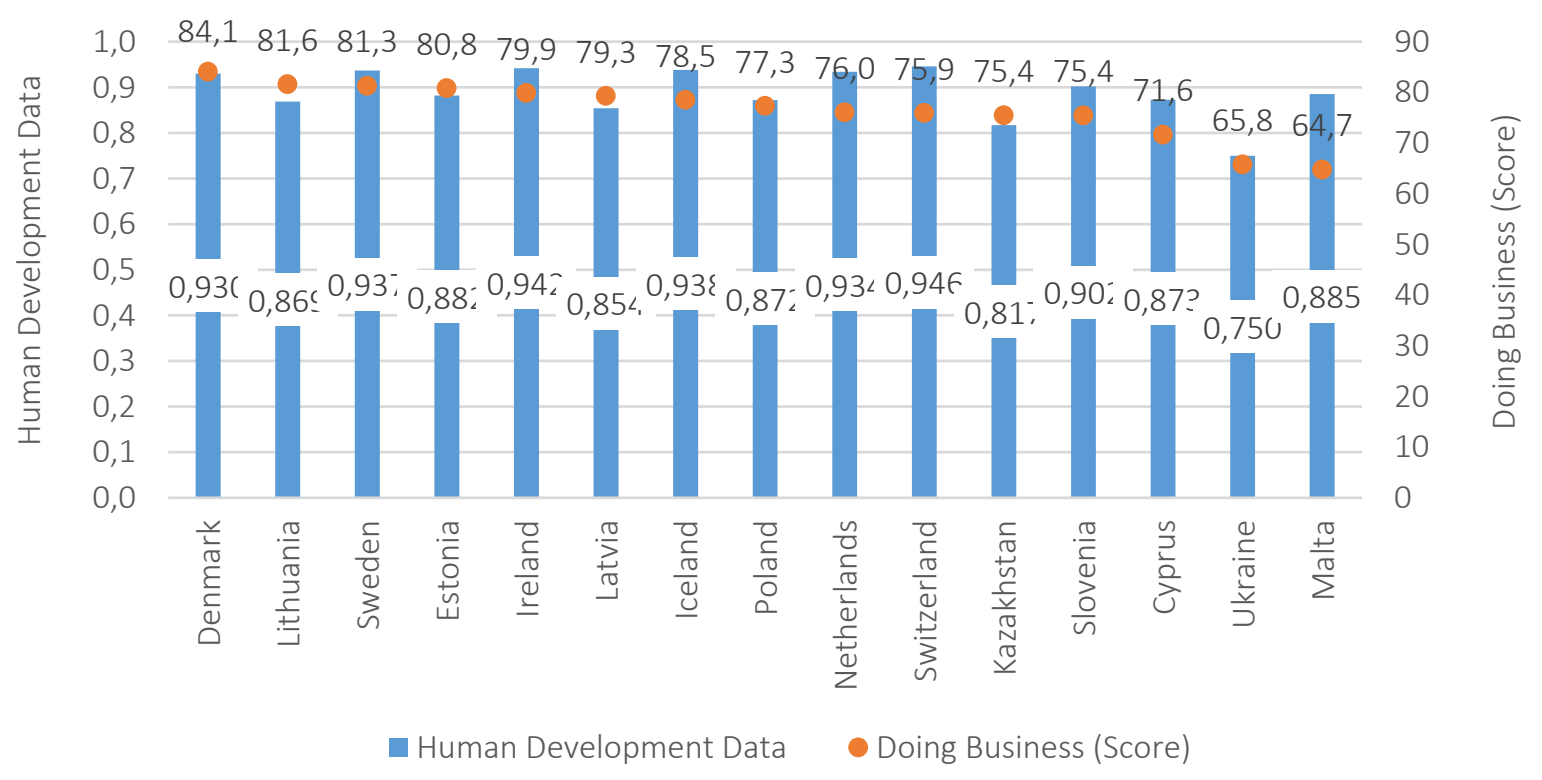

Figure 3. Human Development Index and Doing Business in European countries in 2018

Given the sustainable development of the country and reasonable social and economic reforms, an educated population is the driving force of the formation of competitive business, ensuring a high standard of living and support for idea.

Obviously the living standard is related to the level of economic development of the country, which is provided mainly by the business activity of the country. Doing Business is an indicator, that characterizes the favorable conditions for business organization. The economy is rated for ease of doing business from 1 to 190. A high rate of ease of doing business means that the rights of the companies are more conducive to set up and run business. The ranking is determined by sorting the total scores by ten topics, each of them consists of several indicators, with equal weight to each topic (World Bank Group, 2018).
The analysis of the human development index and doing business in some European countries and Ukraine is presented in Figure 3.

Based on the data in Figure 3, it is found an direct insignificant correlation between the human development index and the doing business indicator $\left(R^{2}\right.$ $=27.29 \%$, the model is adequate to the observational evidence $F_{\text {emp }}=4.88>F_{(0.05 ; 1 ; 13)}=4.75$ and has significant parameters $\left.t_{0}=2.21, t_{1}=2.78>t_{(0.05 ; 13)}=2.16\right)$.

Of course, the ease of doing business is a result of socio-economic reforms and fiscal policy, but in countries where the rules of doing business are difficult, the level of economic development and, consequently, the standard of living are not able to be high.

\section{CONCLUSION}

According to the research aim, the correlation between state funding of higher education and indicators, that characterize the quality and efficiency of higher education in European countries were analyzed.

The analysis showed no significant correlation between the share of education expenditures and the education index. The correlation between the share of higher education expenditures and gross enrolment ratio (tertiary) was not found as well.

It was found the direct correlation between the amount of expenditure per student and the quality index of the higher education system QS World University Rankings; however, expenditure is not a key factor, 
which influences on quality index. This occurs due to the fact that, firstly, educational institutions are funded by private resources in addition to public funding and grant projects as well, and secondly, the education system of each country has its own particularities, which also determine the indicators of higher education effectiveness.

It was also found a direct insignificant correlation between the indicators of the human development index and the doing business index. The better and simpler the system of business, institutions, and organizations are, the more efficient the business environment is, and thus the economic growth and the social standard will improve faster.

\section{AUTHOR CONTRIBUTIONS}

Conceptualization: Victor Chentsov.

Data curation: Olha Hryhorash, Almagul Nurgaliyeva, Tetiana Hryhorash.

Formal analysis: Olha Hryhorash, Tetiana Hryhorash.

Methodology: Olha Hryhorash, Victor Chentsov.

Project administration: Victor Chentsov, Almagul Nurgaliyeva.

Supervision: Victor Chentsov, Almagul Nurgaliyeva.

Visualization: Olha Hryhorash, Tetiana Hryhorash.

Writing - original draft: Olha Hryhorash, Tetiana Hryhorash.

Writing - review \& editing: Victor Chentsov, Almagul Nurgaliyeva.

\section{REFERENCES}

1. Abenov, Ye., Kirdasinova, K., Myrzageldi, K., Uskelenova, A., Nurgaliyeva, A., \& Ismailova, D. (2019). Innovative Development of Entrepreneurship in Kazakhstan within the Framework of the Public-Private Partnership (PPP). Revista Espacios, 40(20). Retrieved from https://www.revistaespacios. com/a19v40n20/a19v40n20p07.pdf

2. Adambekova, A., \& Amankeldy, N. (2016). Education system funding in Kazakhstan: dynamics of education spending: national and international experience. Nauchnyi rezultat. Seriya. Ekonomycheskye yssledovanyia - Scientific result. Economic research, 1(17), 32-37. (In Russian).

3. Antoniuk, L., Ilnytskyi, D., Barabas, D., \& Sandul, M. (2017). International competitive disposition of national higher education systems. Mizhnarodna Ekonomichna Polityka International Economic Policy, 2, 7-39. (In Ukrainian). Retrieved from http://nbuv.gov.ua/UJRN/ Mep_2017_2_3

4. Antoniuk, L., Kalenyuk, L, Tsyrkun, O., \& Sandul, M. (2019).
Rankings in the higher education competitiveness management system. Problems and Perspectives in Management, 17(4), 325-339. http://dx.doi.org/10.21511/ ppm.17(4).2019.27

5. Chernukha, T. (2019). Peculiarities of the institutional blocks of the Ukrainian higher education system in the conditions of economic transformation. Development Management, 17(3), 54-67. http://dx.doi.org/10.21511/ dm.17(3).2019.05

6. Dekhtiar N., \& Yanchenko V. (2018) Financing of the higher education system in Ukraine. Infrastruktura rynku - Market infrastructure, 25, 667-672. (In Ukrainian).

7. Del Boca, D., Monfardini, Ch., \& See, S. G. (2019). Government Education Expenditures, PrePrimary Education and School Performance: A Cross-Country Analysis (IZA Discussion Paper No. 11375). Retrieved from http:// ftp.iza.org/dp11375.pdf

8. Deloitte Access Economics. (2019). Transparency in Higher
Education Expenditure: Australian Government Department of Education. Retrieved from https://docs.education.gov.au/ documents/2019-transparencyhigher-education-expenditurepublication-0

9. Eurostat. (2020). Government expenditure on education. Retrieved from https://ec.europa. eu/eurostat/statistics-explained/ index.php/Government_expenditure_on_education\#Evolution_ of_.27education.27_expenditure_ over_2001-2018

10. Gejger, R., \& Kheller, K. (2012). Trends in Higher Education Funding: USA. Voprosy obrazovaniya - Education issues, 3, 5-29. (In Russian). Retrieved from https://cyberleninka.ru/article/n/ sovremennye-tendentsii-v-finansirovanii-vysshego-obrazovaniyassha/viewer

11. Goksu, A., \& Goksu, G. G. (2015). A Comparative Analysis of Higher Education Financing in Different Countries. Procedia Economics and Finance, 26, 1152-1158. https://doi.org/10.1016/S22125671(15)00945-4 
12. Govindarajan, V., \& Srivastava A. (June 2, 2020). A PostPandemic Strategy for U.S. Higher $E d$. Harvard Business Review. Retrieved from https://hbr. org/2020/06/a-post-pandemicstrategy-for-u-s-higher-ed

13. Hrishyn, A. (2011). Priority of the quality of services of Latvian universities: problems and proposals. Aktualnye problemy obrazovaniya: mezhvuzov. Naucho-prakticheskaya i uchebnometodicheskaya konferentsiya Actual problems of education: interuniversity scientific-practical and educational-methodical conference. Institute of Transport and Communication, Riga. (In Russian). Retrieved from http:// www.tsi.lv/sites/default/files/editor/science/Publikacii/Aktual/Actual_2011/7_arkadiy_grishin.pdf

14. Khovrak, I. (2020). Higher education institutions as a driver of sustainable social development: Polish experience for Ukraine. Environmental Economics, 11(1), 1-13. http://dx.doi.org/10.21511/ ee.11(1).2020.01

15. Miningou, E. W. (2019). Quality Education and the Efficiency of Public Expenditure: A CrossCountry Comparative Analysis (Policy Research Working Paper No. 9077). World Bank, Washington, DC. Retrieved from http://documents1.worldbank.org/ curated/en/751241575986941436/ pdf/Quality-Education-and-theEfficiency-of-Public-ExpenditureA-Cross-Country-ComparativeAnalysis.pdf

16. Ministry of Finance of the Republic of Kazakhstan. (2020). State expenditures on education. (In Russian). Retrieved from https://www.gov.kz/memleket/ entities/minfin?lang=ru

17. Mitchell, M., Leachman, M., \& Saenz, M. (2019). State Higher Education Funding Cuts Have Pushed Costs to Students, Worsened Inequality. Center on Budget and Policy Priorities. Retrieved from https://www.cbpp. org/blog/state-higher-educationcuts-pushed-costs-to-studentsworsened-inequality

18. Moss, D. A., \& Lo, S. (2010). Financing Higher Education in Australia. Harvard Business School Finance case. Retrieved from https://hbsp.harvard.edu/ product/711047-PDF-ENG

19. OECD. (2019). Benchmarking Higher Education System Performance, Higher Education. OECD Publishing, Paris. Retrieved from https://doi. org/10.1787/be5514d7-en

20. QS Top Universities. (2018). QS Higher Education System Strength Rankings. Retrieved from https:// www.topuniversities.com/systemstrength-rankings/2018

21. Sovsun, I. (2016). The new model of higher education funding must be transparent and efficient in the use of budget funds. Ministry of Education and Science of Ukraine. (In Ukrainian). Retrieved from https://mon.gov.ua/ua/news/usinovivni-novini-2016-03-15-innasovsun-nova-model-finansuvannya-vishhoyi-osviti

22. Stadnyi, Ye. (2016). Conceptual model of state funding of universities based on performance results. CEDOS. (In Ukrainian). Retrieved from https://cedos.org. ua/uk/articles/kontseptualnamodel-derzhavnoho-finansuvannia-vnz-za-rezultatamy-diialnosti

23. State Treasury Service of Ukraine. (2020). Expenditures on the program classification of expenditures and lending of the state budget. Retrieved from http:// www.treasury.gov.ua/

24. Stavytskyy, A., Dluhopolskyi, O., Kharlamova, G., Karpukand, F., \& Osetskyi, V. (2019). Testing the fruitfulness of the institutional environment for the development of innovative-entrepreneurial universities in Ukraine. Problems and Perspectives in Management, 17(4), 274-288. https://doi. org/10.21511/ppm.17(4).2019.23

25. Stryhul, M., Khomeriki, O., Yahodzinskyi, S., Lyasota, L., \& Semenets-Orlova, I. (2019). Peculiarities of development and dynamics of economism and the commercialization of Ukrainian higher education. Problems and Perspectives in Management, 17(2), 289-302. https://doi.org/10.21511/ ppm.17(2).2019.22
26. The Pew Charitable Trusts. (2019). Two Decades of Change in Federal and State Higher Education Funding. Retrieved from https:// www.pewtrusts.org/-/media/assets/2019/10/fedstatefundinghigheredu_chartbook_v1.pdf

27. United Nations Development Programme (UNDP). (2018). Human Development Indices and Indicators: 2018 Statistical Update. Retrieved from http://hdr.undp. org/en/content/human-development-index-hdi

28. Usyk, V. (2019). Particularities of higher education funding: analysis of Ukrainian and world contexts. Visnyk Kyivskoho natsionalnoho universytetu im. Tarasa Shevchenka. Seriia: Ekonomika Bulletin of Kyiv National University named after Taras Shevchenko. Series: Economics, 2(203), 59-67. (In Ukrainian). Retrieved from https://ideas.repec.org/a/scn/ pnoeeq/203a8.html

29. World Bank Group. (2018). Doing Business 2018. International Bank for Reconstruction and Development/The World Bank. Retrieved from https://www.doingbusiness.org/en/reports/globalreports/doing-business-2018 